Part 3

Translating Human Rights into Law 



\title{
The impact of legal aid cuts on access to justice in the UK
}

\author{
Smita Shah
}

Lawyers would argue that this is an epochal moment for access to justice in the UK. Time will judge in due course; for now it worth simply setting a marker down to capture what has passed. The date to note is 1 April 2013: this was when the Legal Aid, Sentencing and Punishment of Offenders Act 2012 (LASPO), an Act of Parliament of the United Kingdom, came into affect. LASPO changed the landscape of civil legal aid in England and Wales ${ }^{1}$ not only in how and by whom legal aid was administered; LASPO profoundly altered what remained within scope for legal aid, taking private family law disputes such as divorce and child custody, immigration, housing, debt and social welfare and employment out of the provision of legal aid save for those cases where 'domestic violence is involved, life or liberty are at stake or people risk losing their home' (BBC 2013). The cuts were introduced with the aim to shave off $£ 350$ million from the $£ 2$ billion civil and criminal legal aid budget, primarily in civil legal aid with proposals for eventual cuts in criminal legal aid. For a nation in financially difficult times following the banking crisis of 2008 and subsequent recession, the retrenchment of the public services was bitter surgery the nation would have to endure. Why would the provision of legal aid be immune from excision?

At the time, LASPO faced an avalanche of criticism from: the judiciary; both arms of the legal profession (solicitors represented through The Law Society and barristers represented through the Bar Council); Citizens Advice Bureaux; Law Centres; the advice sector; non-governmental organisations; and eventually even the UN Committee on the Elimination of Discrimination against Women ${ }^{2}$ for the impact such cuts would have on access to justice for the most vulnerable members of society. A deferential, conservative and competitively

1 Scotland and Northern Ireland are subject to their own provisions due to devolution and legal aid remains available in Scotland.

2 United Nations Committee on the Elimination of Discrimination against Women, Concluding observations on the seventh periodic report of the United Kingdom of Great Britain and Northern Ireland, UN Doc. CEDAW/C/GBR/CO/7 (30 July 2013). 
divided profession (solicitors and barristers) unified and revolted: the Criminal Bar Association aligned itself with criminal law solicitors, while the Justice Alliance unified the civil wing of the professions and called for protests and boycotts of court proceedings, despite the threat of possible disciplinary action by the Bar Standards Board on barristers taking part. ${ }^{3}$ The government of the day countered with accusations of self-interest and self-enrichment on the part of the legal profession.

Self-interest notwithstanding, it is worth taking a step back to consider what the United Nations Basic Principles on the Role of Lawyers (1990), sets out in its preamble: 'Whereas adequate protection of the human rights and fundamental freedoms to which all persons are entitled, be they economic, social and cultural, or civil and political, requires that all persons have effective access to legal services provided by an independent legal profession'. The Basic Principles set out not only the role of lawyers, their duties and responsibilities. Governmental obligations are to ensure that access is equal and effective to all persons within their territory and subject to their jurisdiction (Principle 2) and that there is sufficient funding to ensure access for those who are disadvantaged (Principle 3). Note also a special emphasis upon the important role of lawyers in protecting their fundamental freedoms' (Principle 4). Lawyers are the medium and the conduits to ensure access to justice.

How do LASPO legal aid reforms sit within the commitment the UK has to ensure access to justice? International human rights law has much comfort to offer here. Access to justice has commonly been thought of as a facilitative right, a right without which others cannot be enforced (Articles 2(3), 3, 26 ICCPR, Articles 5, 6 ICERD, Article 2(2) ICESCR, Article 2 CEDAW and soft law in the form of the UN Principles and Guidelines on Access to Legal Aid in Criminal Justice System (2012)). When placed within the menu of the rule of law principles, it has increasingly come to have a value in and of itself.

The Inter-American Court of Human Rights, in considering the American Convention on Human Rights, has pronounced that the State's failure to provide legal aid necessary to enable the effective exercise of a form of legal

3 BBC (2015), Lawyers protesting outside courts over legal aid cuts (6 Jan. 2014), available at http://www.bbc.co.uk/news/uk-25597617(accessed 8 Oct. 2015); Owen Bowcott, Peter Walker and Lisa O'Carroll (2014), 'Courts close across England and Wales as lawyers protest at legal aid cuts', The Guardian (6 Jan. 2014), available at http://www.theguardian.com/law/2014/jan/06/courts-close-englandwales-lawyers-legal-aid-cuts (accessed 8 Oct. 2015); James Cusick (2015), Legal aid cuts: Criminal courts across England and Wales could grind to a halt as lawyers protest, The Independent (26 June 2015), available at http://www.independent. co.uk/news/uk/home-news/criminal-courts-across-england-and-wales-couldgrind-to-a-halt-as-lawyers-protest-legal-aid-cuts-10346409.html (accessed 8 Oct. 2015); Justice Alliance (2015), Legal aid cuts threaten our very democracy, available at https://justiceallianceuk.wordpress.com (accessed 8 Oct. 2015). 
recourse renders that recourse illusory and that this constitutes a violation by the state of Article 1(1), 8 and 25 of the Convention (Hilaire, Constantine and Benjamin et al v. Trinidad and Tobago Judgement 21 June 2002).

Article 14 (3) (d) ICCPR and Article 6(3)(c) of the European Convention for the Protection of Human Rights and Fundamental Freedoms explicitly set out governmental obligations for the provision of legal aid in criminal justice. Jurisprudence from the European Court of Human Rights when considering Article 6(3)(c) has elaborated that this has a means (indigence) and merits (the interests of justice) test for the provision of legal aid (Artico v. Italy, Judgment of May 13, 1980, Pakelli v. Germany, Judgment of April 25, 1983 and Quaranta v. Switzerland, Judgment of May 24, 1991).

What of civil legal aid? In the Airey v. Ireland, Judgment of October 9, 1979, the European Court of Human Rights found that Article 6 (1) also implies the right to free legal assistance in certain civil cases. Mrs Airey sought free legal assistance to institute divorce proceedings against her abusive husband, who refused to sign a voluntary separation agreement. While not an absolute right, and subject to curtailment in circumstances, the Court ruled that the right applies in civil cases when such assistance proves indispensable for effective access to the courts, either because legal representation is mandatory under domestic law or because of the complexity of the procedure or the type of case. The fact is that the case concerned a marital dispute entailing emotional involvement incompatible with the level of objectivity required by advocacy in court.

Have these legal aid reforms created institutional, structural and actual barriers impeding access to justice? Sadly, many of the dire predictions came to pass: an impact assessment by Warwick University in April 2013 entitled The State of the Sector warned of advice deserts in patches across England and Wales (Byrom 2013). In March 2015, the Parliamentary Justice Committee reported on the impact of the changes to civil legal aid under LASPO. The Justice Committee was told that nine law centres had shut down (one in six of the law centre network members) and ten such centres run by Shelter (a homelessness charity). ${ }^{4}$ Local Authorities have faced cuts in grants from central government and they have in turn stopped funding law centres. A Rights of Women survey found that 31.3 per cent of respondents reported that finding a legal aid solicitor in her area was difficult, with some respondents reported to having to travel between five and 15 miles to find a legal aid solicitor. Factors such as closure of legal aid law firms, legal aid departments within firms, smaller law firms merging or being swallowed by medium to larger law firms all meant

4 House of Commons Justice Committee, Eighth Report of Session 2014-15, 4 March 2015: Impact of Changes to civil legal aid under Part 1 of the Legal Aid, Sentencing and Punishment of Offenders Act 2012, available at http://www.publications.parliament. $\mathrm{uk} / \mathrm{pa} / \mathrm{cm} 201415 / \mathrm{cmselect} / \mathrm{cm}$ just/311/31102.htm (accessed 8 Mar. 2015). 
specialist solicitors who carried out legal aid work in areas such as housing, family and immigration were not longer available or accessible.

LASPO created a gateway for victims of domestic violence to be able to access legal aid, as long as they could navigate the gateway and provide evidence to demonstrate their victim status. Evidence accepted by the Justice Select Committee suggested that as many as 39 per cent of women eligible for legal aid through the domestic violence gateway were unable to access legal aid and hence justice. A Rights of Women survey carried out in 2014 reported 62.1 per cent of respondents were not already in possession of the evidence they required, and 77.8 per cent of those respondents reported that they did not know who to ask to obtain a copy of it. 22.7 per cent of respondents had to wait for longer than two weeks to receive a copy of the required evidence. ${ }^{5}$ Women, even those on benefits, were required to pay $£ 50$ for a letter from the doctor as proof or $£ 60$ for a memorandum of conviction. Owing to the strict evidence criteria, some of those excluded are victims who reached out to women's support groups, but not to the authorities; women who called the police but whose calls were unanswered; or women who did not call the police or see a doctor, because they suffered no serious physical injuries (UNHRC 2015).

The cuts came against a backdrop marketisation of all areas of the justice system, which had been happening by stealth for a number of years (Genn 2012). Between 2006 and 2009, the legal profession and legal advice sector faced a cap in the fees regime. In 2011, there was a 10 per cent cut across the board in all areas of legal aid. The Legal Services Act 2007 enabled general legal advice to be given by non-lawyers thereby challenging the monopoly the legal profession had upon the provision of legal services. The Bar Standards Board (BSB) had started to publish a biennial survey of its profession and the background of those practising - a taking-stock exercise about the Bar and Barristers. In 2011 and 2013, the BSB found that 37 and 35 per cent of the profession were female. In 2013 and in 2011, 61 per cent of family practitioners were female, the area hardest hit by the legal aid cuts. The BSB Biennial Survey indicated that the majority of the white, male and Oxbridgeeducated barristers are in chancery, commercial and privately paying areas of law, which have been traditionally difficult for women and BME (Black and minority ethnic) candidates to break into. Family, immigration, housing, and crime had been traditionally more accessible to candidates from state schools,

5 Right of Women's evidence to the Justice Select Committee on the impact of changes to civil legal aid under the Legal Aid, Sentencing and Punishment of Offenders Act 2012 dated April 2014, available at http://rightsofwomen.org.uk/ wp-content/uploads/2014/10/Evidence-to-the-Justice-Select-Committee-on-theimpact-of-changes-to.pdf (accessed 8 Oct. 2015). 
the Russell group or newer universities and are predominantly legal-aid practitioners. ${ }^{6}$

LASPO embraced a programme of continued privatisation of prisons (Poyner 2012), privatisation of the probation service (Travis 2014), cuts to the budget of Her Majesty's Courts and Tribunals Service (Hyde 2012; 2015), an increase in court fees for employment dispute cases, divorce applications and the on-going closure of court houses themselves (157 court houses in 2010 and a further 91 court houses proposed in July 2015) (Family Law Week n.d.; BBC 2015).

The cuts in legal aid were designed to divert people away from contentious litigation and towards mediation and alternate dispute resolution; this did not happen for the simple reason that there was no accompanying mass public awareness and education campaign. The public became aware that civil legal aid was no more and stopped going to see lawyers; they did not, to the horror of the courts, stop seeking resolution of disputes through the court. Hence the rise in litigants in person and increasing delays in court. Alternate legal services providers have sprung up to fill the void, including self-help guides available on the internet, over the telephone, or in books; unregulated services such as McKenzie Friends (who are allowed to assist but not act as lawyers in court), student law clinics and pro bono services by larger commercial law firms. The latter remains controversial within the legal profession, the dilemma being to legitimise the erosion of access to justice by filling the void left by professional flight of experienced legal aid lawyers.

How does marketisation of the justice system sit within a state obligation to ensure access to justice and legal aid? The desire on the part of successive governments has been to promote informal resolution of legal disputes, diversion away from the formal justice system and privatisation of institutions and actors. In order to achieve this, the public are required to engage with these different means of resolving legal dispute; the cuts in civil legal aid did not have the corresponding change in public behaviour. Perceptions of justice, fairness and adjudication still involve lawyers, courts and trials. The difference is now qualitative; access to justice has migrated from being an entitlement the state is obliged to provide for to an act of charity, fulfilled at the behest of the goodwill of unaccountable others. This is a precarious position for any human right to be in.

6 Bar Standards Board (2014), Barristers' Working Lives: a second biennial survey of the bar 2013, available at https://www.barstandardsboard.org.uk/media/1597662/ biennial_survey_report_2013.pdf (accessed 16 June 2015). Bar Standards Board (2012), Barristers' Working Lives: a second biennial survey of the bar 2011, available at https://www.barstandardsboard.org.uk/media/1385164/barristers_working_ lives_30.01.12_web.pdf (accessed 16 June 2015). 


\section{Bibliography}

BBC (2013) Q\&A: Legal aid changes (20 March 2013), available at http:// www.bbc.co.uk/news/uk-21668005 (accessed 8 Oct. 2015).

Byrom, N. (2013) The State of the Sector: The impact of cuts and civil legal aid on practitioners and her clients, A Report by the Centre for Human Rights in Practice, University of Warwick in association with illegal, available at http://www2.warwick.ac.uk/fac/soc/law/research/centres/chrp/projects/ legalaidcuts/153064_statesector_report-final.pdf (accessed 8 Oct. 2015).

Family Law Week (n.d.) Ministry of justice proposes closure of 157 courts, available at http://www.familylawweek.co.uk/site.aspx?i=ed60918 (accessed 8 Oct. 2015); BBC (16 July 2015), Ninety one 'surplus' courts face closure, available at http://www.bbc.co.uk/news/uk-33549588 (accessed 8 Oct. 2015).

Genn, H. (2012) 'Why privatisation of civil justice is a rule of law issue' F. A. Mann lecture, available at http://www.laws.ucl.ac.uk/wp-content/ uploads/2014/08/36th-F-A-Mann-Lecture-19.11.12-Professor-HazelGenn.pdf (accessed 8 Oct. 2015).

Hyde, J. (2015) 'HMCTS reveals plans to cut 400 court jobs', The Law Society Gazette (22 June 2015), available at http://www.lawgazette. co.uk/news/hmcts-reveals-plans-to-cut-400-court-jobs/5049543.article (accessed 8 Oct. 2015).

Hyde, J. (2012) 'Hundreds of court posts axed', The Law Society Gazette (19 Jan. 2012), available at http://www.lawgazette.co.uk/news/hundreds-ofcourt-posts-axed/63809. fullarticle (accessed 8 Oct. 2015).

Pyner, C. (2012) 'Prison privatisation should be a national scandal', The Guardian (8 Nov.2012), available at http://www.theguardian.com/ commentisfree/2012/nov/08/prison-privatisation-g4s-wolds (accessed 8 Oct. 2015).

Travis, A. (2014) 'Chris Grayling to press ahead with probation service privatisation', The Guardian (2 Dec. 2014), available at http://www. theguardian.com/society/2014/dec/02/chris-grayling-probation-serviceprivatisation (accessed 8 Oct. 2015).

UN Human Rights Council (UNHRC) (2015) Report of the Special Rapporteur on violence against women, its causes and consequences, Rashida Manjoo Mission to the United Kingdom and Northern Ireland, UN Doc. A/ HRC/29/27/Add.2 (19 May 2015). 